\title{
O IMPÉRIO DA VISÃO FOTOGRAFIA NO CONTEXTO COLONIAL PORTUGUÊS (1860-1960)
}

\author{
RUTE VIEIRA ${ }^{1}$
}

Nos dias 26 e 27 de Setembro de 2013, decorreu no Instituto de Ciências Sociais (ICS), um colóquio sobre "O Império da Visão: Fotografia no contexto colonial português (1860-1960)". O colóquio foi organizado pela investigadora desse instituto, Filipa Lowndes Vicente, e pretendeu reunir a diversidade de olhares que, nos anos recentes, se têm vindo a produzir na academia, sobre este período da história da cultura visual portuguesa.

O colóquio foi aberto por Filipa Lowndes Vicente que apresentou o trabalho que a sua equipa de investigação tem levado a cabo no âmbito da fotografia no contexto colonial português entre 1860-1960, através do seu projecto de investigação no ICS, Goa em Exposição: Exposições, Imagens e Identidades (1850-1950), sobre a produção de conhecimento em contexto colonial, numa perspectiva histórica, mas igualmente antropológica, cultural e visual.

No primeiro dia, as apresentações centraram-se em dois temas: "Missões e Antropologia" e "Conhecimento e Circulação".

No tema "Missões e Antropologia" foram apresentadas quatros comunicações.

Ricardo Roque apresentou $O$ arquivo colonial e as fotografias do capitão Fonseca Cardoso (1865-1912), onde explorou as possibilidades e limitações interpretativas do arquivo de fotografias coloniais desse capitão do exército português e administrador colonial.

Cristina Nogueira da Silva falou sobre $O$ registo da diferença: fotografia e classificação jurídica das populações coloniais. Pretendia reflectir sobre o modo como algumas populações nativas de Moçambique foram retratadas, num conjunto de álbuns fotográficos do princípio do século XX, ligando-o com as classificações propostas pela doutrina jurídico-colonial portuguesa dos finais do século XIX e início do século XX.

Ana Cristina Roque e Ana Cristina Martins discutiram, respectivamente, a importância da fotografia na missão antropológica de Moçambique (1936-1956) e na missão antropológica e etnológica da Guiné (1946-1947).

1 Bolseira de Gestão de Ciência e Tecnologia no Centro de Estudos Geográficos da Universidade de Lisboa. E-mail: rutevieira@campus.ul.pt 
Patrícia Ferraz de Matos encerrou o tema com a apresentação do papel que a fotografia teve, enquanto instrumento de documentação e auxiliar das práticas antropológicas da primeira metade do século XX, a partir da obra do antropólogo Mendes Correia.

O tema "Conhecimento e Circulação" foi alvo de quatro comunicações.

António Carmo Gouveia referiu a importância da fotografia para a descrição e inventariação das plantas tropicais nos finais do século XIX.

Paulo Jorge Fernandes expôs a importância da Missão de Mariano de Carvalho à província de Moçambique, em 1890, na qual foi acompanhado por um fotógrafo, que registou a realidade observada pelo antigo ministro.

Teresa Mendes Flores analisou a documentação fotográfica dos relatórios médicos da empresa de diamantes angolana, Diamang. Esta empresa era um exemplo de modelo de colonização segregacionista, mantendo os negros nos arredores das cidades em condições de habitação precárias, embora tivesse preocupações com a saúde dos nativos e o controlo da sua «robustez física» para o trabalho, bem visível nos relatórios médicos e nas fotografias que os acompanhavam.

A nudez e a sedução em contexto colonial foram tratadas, respectivamente, por Clara Carvalho e Mário Machaqueiro. A primeira apresentação focou-se na nudez representada no Arquivo Etnográfico da Guiné-Bissau; a segunda nas imagens muçulmanas, nomeadamente de Moçambique, que serviram de propaganda e que encenavam uma ideia de harmonia entre os muçulmanos de África e o regime colonial, de modo a atraí-los para o lado português na guerra contra a Frelimo.

No segundo dia, os temas abordados reportaram-se a "Exposições e Reproduções", "Resistência e Revolta" e, ainda, a questões relativas a "Arquivar e Revelar".

No tema "Exposições e Reproduções” Leonor Martins mostrou como algumas fotografias foram divulgadas em forma de gravuras, nem sempre fiéis às fotografias que lhes deram origem.

Teresa Castro mostrou como a fotografia, em contexto colonial, funciona como meio de documentação e recolha e também como cartografia visual, considerando, por isso, que alguns álbuns são autênticos atlas.

Inês Vieira Gomes abordou o caso das Exposições de fotografia no Palácio da Foz (1938-1951) realizadas em parceria com a Agência Geral das Colónias e o Secretariado de Propaganda Nacional/Secretariado Nacional da Informação (SPN/SNI). Nesse período foram feitas quatro exposições de fotografias de Angola e de Moçambique, que constituíram bons exemplos do uso da fotografia para dar a conhecer as colónias junto do público na metrópole.

O tema "Resistência e Revolta" contou com duas comunicações.

Afonso Ramos mostrou e comentou fotografias que retractaram os massacres da União dos Povos de Angola (UPA) no norte de Angola em 1961. Essas imagens documentam bem as atrocidades cometidas em tempo colonial.

Catrina Laranjeiro e Carlos Barradas abordaram a importância da fotografia para a caracterização da ocupação colonial e Susana Martins mostrou como a fotografia pós-colonial consegue transmitir as complexas heranças históricas do tempo colonial.

Na temática “Arquivar e Revelar", Ana Gandum e Inês Abreu e Silva apresentaram o projecto Foto-Síntese, que diz respeito a um sítio online onde se encontra um arquivo digital de fotografia analógica vernacular portuguesa, lançado em Novembro de 2013.

Catarina Mateus encerrou as apresentações dando a conhecer a organização das colecções de fotografia do Instituto de Investigação Científica Tropical (IICT), a forma de restauro, de conservação e de acesso às mesmas. 
A convite da organização, Rute Vieira, colaboradora na Fototeca do CEG, participou no colóquio aproveitando a oportunidade para apresentar o espólio fotográfico deste Centro, integrado no tema "Arquivar e Revelar". Este arquivo conta com cerca de 55000 espécimes fotográficos, entre a colecção de diapositivos e a de fotografias a preto e branco. O espólio inclui essencialmente o território nacional e as antigas colónias - Guiné, Cabo Verde, Angola, Moçambique, Brasil, além de outros países dos continentes africano e americano -, com múltiplas visões desses territórios em aspectos variados da Geografia, entre as décadas 40 e 90 do século XX. São fruto do trabalho de campo desenvolvido pelos principais investigadores do Centro de Estudos Geográficos, criado em 1943, nomeadamente, Orlando Ribeiro, Raquel Soeiro de Brito, Ilídio do Amaral, Suzanne Daveau, Jorge Gaspar, entre outros. O acervo de diapositivos está disponível em formato digital e as fotografias a preto e branco na maioria em suporte de papel.

Actualmente os espécimes fotográficos são utilizadas no ensino, mas sobretudo na investigação, nomeadamente em dissertações de mestrado e teses de doutoramento e em publicações várias, como revistas, livros ou documentários.

Foram divulgadas algumas das dificuldades sentidas na Fototeca, particularmente a falta de condições adequadas para a conservação das espécies, sentidas aliás por todos os presentes que trabalham na área. Outro ponto comum está na dificuldade em catalogar todo o arquivo fotográfico, existindo por isso muito material "cego". O inventário da Colecção da Fototeca não está acessível online mas é pretensão futura, que ele se torne assim mais facilmente acessível à comunidade interessada no mesmo.

A participação no colóquio permitiu reforçar o contacto com Catarina Mateus, responsável pelo espólio do IICT, com quem se espera colaborar, de futuro, para o melhoramento das condições de conservação e restauro do espólio da Fototeca.

\section{AGRADECIMENTOS}

A autora agradece, à Professora Maria João Alcoforado e à Professora Maria Fernanda Alegria, a revisão do texto e as sugestões, que contribuíram para a melhoria da qualidade do mesmo. 